Article

\title{
Benzylsuccinate Synthase is Post-Transcriptionally Regulated in the Toluene-Degrading Denitrifier Magnetospirillum sp. Strain 15-1
}

\author{
Ingrid Meyer-Cifuentes ${ }^{1,2}{ }^{,}$Sylvie Gruhl ${ }^{1}$, Sven-Bastiaan Haange ${ }^{3}{ }^{(0)}$, Vanessa Lünsmann ${ }^{3}$, \\ Nico Jehmlich ${ }^{3}$, Martin von Bergen ${ }^{3,4}$, Hermann J. Heipieper ${ }^{1, *(1)}$ and Jochen A. Müller ${ }^{1}$ (I) \\ 1 Department of Environmental Biotechnology, Helmholtz Centre for Environmental Research - UFZ, \\ Permoserstr. 15, 04318 Leipzig, Germany; ingrid.meyer.cifuentes@dsmz.de (I.M.-C.); \\ sylvie.gruhl@outlook.de (S.G.); jochen.mueller@ufz.de (J.A.M.) \\ 2 Junior Research Group of Microbial Biotechnology, Leibniz Institute DSMZ, German Collection of \\ Microorganisms and Cell Cultures, Inhoffenstr. 7B, 38124 Braunschweig, Germany \\ 3 Department of Molecular Systems Biology Helmholtz Centre for Environmental Research-UFZ, Permoserstr. \\ 15, 04318 Leipzig, Germany; sven.haange@ufz.de (S.-B.H.); vanessa.luensmann@posteo.de (V.L.); \\ nico.jehmlich@ufz.de (N.J.); martin.vonbergen@ufz.de (M.v.B.) \\ 4 Group of Functional Proteomics, Institute of Biochemistry, Faculty of Biosciences, Pharmacy and Psychology \\ University of Leipzig, Talstrastr. 33, 04103 Leipzig, Germany \\ * Correspondence: hermann.heipieper@ufz.de; Tel.: +49-341-2351694
}

Received: 1 April 2020; Accepted: 4 May 2020; Published: 7 May 2020

check for updates

\begin{abstract}
The facultative denitrifying alphaproteobacterium Magnetospirillum sp. strain 15-1 had been isolated from the hypoxic rhizosphere of a constructed wetland model fed with toluene. This bacterium can catabolize toluene anaerobically but not aerobically. Here, we used strain 15-1 to investigate regulation of expression of the highly oxygen-sensitive glycyl radical enzyme benzylsuccinate synthase, which catalyzes the first step in anaerobic toluene degradation. In cells growing aerobically with benzoate, the addition of toluene resulted in a $\sim 20$-fold increased transcription of $b s s A$, encoding for the catalytically active subunit of the enzyme. Under anoxic conditions, $b s s A$ mRNA copy numbers were up to 129-fold higher in cells growing with toluene as compared to cells growing with benzoate. Proteomics showed that abundance of benzylsuccinate synthase increased in cells growing anaerobically with toluene. In contrast, peptides of this enzyme were never detected in oxic conditions. These findings show that synthesis of benzylsuccinate synthase was under stringent post-transcriptional control in the presence of oxygen, which is a novel level of regulation for glycyl radical enzymes.
\end{abstract}

Keywords: toluene; nitrate; benzylsuccinate synthase; Magnetospirillum; rhizosphere

\section{Introduction}

Microbial toluene degradation has been extensively studied, resulting in the detailed description of one anaerobic and various aerobic catabolic pathways for this aromatic compound [1-4]. Anaerobic degradation is initiated by benzylsuccinate synthase (BSS, encoded by bss genes), which adds a molecule of fumarate to the methyl group of toluene $[5,6]$. The generated benzylsuccinate is transformed to benzoyl-CoA in a $\beta$-oxidation-like scheme involving enzymes encoded by the $b b s$ genes [7]. Benzoyl-CoA is then reductively dearomatized either by an ATP-dependent Class I benzoyl-CoA reductase $(B c r A B C D)$ in facultative anaerobes or by a non-homologous ATP-independent Class II reductase in various strict anaerobes [8,9]. Further transformation yields central metabolites. 
BSS is an $(\alpha \beta \gamma)_{2}$ heterohexamer and belongs to the family of glycyl radical enzymes (GREs), class II [5,10-12]. The large $\alpha$ subunit (BssA) when activated contains the glycyl radical [6], whereas the small $\beta$ (BssB) and $\gamma$ (BssC) subunits are potentially needed for formation, solubility and stability of a catalytically competent enzyme [5,6]. The glycyl radical is generated post-translationally by an activating enzyme, BssD [5,6]. Glycyl radical chemistry is incompatible with oxic conditions. The active form of BSS is oxygenolytically cleaved at the glycyl radical site [13]. Its inactive form is already oxygen sensitive, likely due to the presence of a [4Fe4S]-cluster of apparently very low midpoint potential in each of the small subunits [14,15].

The genomic organization of $b s s$ and $b b s$ genes has been described in ample detail $[1,8,16,17]$. Common to all sequenced anaerobic toluene degraders are $b s s D C A B E F$ and $b b s A B C D E F G H$ gene clusters with shared syntenies. The genes $b s s E$ and $b s s F$ encode for members of the AAA+ and von Willebrand factor protein superfamilies, respectively, but their precise function is uncertain. All sequenced denitrifying and some sulfate-reducing toluene degraders harbour also the bssGIJKL genes which have only general function predictions, and several strains carry additional genes apparently associated with anaerobic toluene transformation such as $b s s H$, predicted to encode for a transporter, and various $x y l R$-type regulators.

There is some genetic knowledge on regulation of expression of the $b s s$ and $b b s$ genes, but sensory inputs are not well defined. In denitrifying strains, expression of apparently both gene clusters is controlled by a two-component regulatory system encoded by the nearby located tdiSR genes [18-20]. The physiologically important inducer for this system could be either toluene or benzylsuccinate [16, $21,22]$. The regulatory impact of oxygen is uncertain and may even differ among strains $[16,23,24]$. It was furthermore proposed that in denitrifiers the level of gene expression is linked to the availability of the terminal electron acceptor nitrate [25]. An improved understanding of regulatory schemes will help to better predict anaerobic toluene degradation in the environment.

We have been investigating microbial in situ degradation of toluene in the rhizosphere of Planted Fixed-bed Reactors (PFRs) [26], which are model systems for analysing processes taking place in constructed wetlands [27]. Although the pore water of the PFRs was typically oxic and protein-based stable isotope probing provided clear evidence for aerobic but not for anaerobic toluene metabolism, $b s s A$ transcript levels surpassed the abundance of every quantified transcript required for aerobic toluene degradation by at least an order of magnitude [27]. Metagenomics and sequencing of $b s s A$ clone libraries indicated that almost all of those transcripts were generated by members of the genus Magnetospirillum, which constituted up to $6 \%$ of the rhizospheric bacterial community. Yet there was no metaproteomics evidence for the presence of BSS in the PFRs even so various peptides of likely Magnetospirillum origin, including some derived from benzoyl-CoA reductase, were found [27]. Subsequently, a representative anaerobic toluene degrader, Magnetospirillum sp. 15-1, was isolated from a PFR and a draft genome sequence of this microbe was generated [28,29]. A physiological characterization, together with an extensive genomic analysis, revealed that the strain degrades toluene anaerobically but not aerobically.

The key aim of this study was to investigate the effect of oxygen and toluene on bss gene expression and synthesis of BSS in growing cells of Magnetospirillum sp. 15-1. Furthermore, the expression of BSS was studied under nitrate-reducing conditions with various nitrate concentrations.

\section{Materials and Methods}

\subsection{Growth Medium and Cultivation}

All cultivations of strain Magnetospirillum sp. 15-1 were performed in a mineral medium previously described by Tschech and Fuchs [30]. For anaerobic cultivation of strain 15-1, the medium was prepared anoxically with either toluene or benzoate as the sole carbon source and various concentrations of nitrate as the electron acceptor. The medium was amended with the reducing agent $\mathrm{Na}_{2} \mathrm{~S}(0.25 \mathrm{mM})$ and the redox indicator resazurin $(0.8 \mu \mathrm{M})$. Subsequently, $100 \mathrm{~mL}$ each of the mineral medium was 
filled into $240 \mathrm{~mL}$-serum bottles and flushed with $\mathrm{N}_{2}$ for $20 \mathrm{~min}$. The bottles were then sealed with teflon-coated stoppers, crimped and autoclaved. $\mathrm{FeSO}_{4}, \mathrm{MgCl}_{2}, \mathrm{CaCl}_{2}$, and vitamins were then added from anoxic and sterile stock solutions. For aerobic cultivation, benzoate $(2.5 \mathrm{mM})$ was always used as the sole carbon and electron source since strain 15-1 is unable to use toluene under oxic conditions [29]. Under this condition, $\mathrm{Na}_{2} \mathrm{~S}$, resazurin and $\mathrm{KNO}_{3}$ were omitted, cultures were shaken and aseptic gaseous exchange with the ambient atmosphere was permitted. Aeration for aerobic cultivation was assured by using only $50 \mathrm{~mL}$ of the mineral media in $240 \mathrm{~mL}$ serum bottles. For anaerobic and aerobic cultivation, the $\mathrm{pH}$ was adjusted to 7.1 with $1 \mathrm{M} \mathrm{NaOH}$. Incubations were performed in triplicate or duplicate at $30^{\circ} \mathrm{C}$ and bacterial growth was assessed by measuring optical density with a spectrophotometer (UV/VIS Spectrometer Lambda 2S, Perkin-Elmer, Waltham, MA, USA) at $560 \mathrm{~nm}$.

To record gene expression and proteins synthesis under oxic conditions, cultures were supplied with benzoate $(2.5 \mathrm{mM})$ as the carbon source to promote bacterial growth. In the following the abbreviation $\mathrm{AB}$ is used for this cultivation condition. Toluene alone $(0.3 \mathrm{mM})\left(\mathrm{AB} \_\mathrm{T}\right)$ and together with $5 \mathrm{mM} \mathrm{KNO}_{3}\left(\mathrm{AB}_{-} \mathrm{TN}\right)$ were tested as inducers. Benzoate alone $(2.5 \mathrm{mM})$ was used as the reference (AB_B) culture. Cultures growing exponentially with $5 \mathrm{mM}$ benzoate as sole carbon source under oxic conditions were used as pre-inoculum. Under anoxic condition various concentrations of nitrate (2.5-10 $\mathrm{mM} \mathrm{KNO}_{3}$ ) were tested with $0.5 \mathrm{mM}$ toluene. Cells grown with $2.5 \mathrm{mM}$ benzoate supplied with 2.5-10 $\mathrm{mM} \mathrm{KNO}_{3}$ were used as the reference. In the following the abbreviation AN is used for this cultivation condition. For the various nitrate concentrations and $0.5 \mathrm{mM}$ toluene, the cultures were designated as: AN_T2.5 (2.5 mM KNO 3$)$; AN_T5 (5 mM KNO 3$)$ and AN_T10 (10 mM KNO $\mathrm{mM}_{3}$. These cultures were incubated in parallel with their corresponding reference culture containing the various nitrate conditions and benzoate alone: AN_B2.5, AN_B5 and AN_B10. Cultures growing exponentially with $1 \mathrm{mM}$ toluene and $10 \mathrm{mM} \mathrm{KNO}_{3}$ under anoxic conditions were used as pre-inoculum. For the pre-inoculum, toluene and nitrate were supplied before depletion. Thereby, cultures received twice $0.5 \mathrm{mM}$ toluene and $5 \mathrm{mM} \mathrm{KNO}_{3}$. The first injection was supplied after bacterial inoculation in fresh media and the second injection after depletion of toluene. Injections of toluene were performed with a $10 \mu \mathrm{L}$ Hamilton syringe 801 RN (Hamilton, Reno, NV, USA). Depletions of toluene and nitrate were measured as described before [29].

AN cultures were harvested in exponential phase before toluene and nitrate depletion. Harvesting points were chosen based on growth experiments in which toluene, benzoate, nitrate, and nitrite were measured [29] (Section S2.1). Bacterial growth and organic carbon consumption are shown in Figure S1.

\subsection{RNA Extraction and cDNA Synthesis}

For RNA isolation, cells of strain 15-1 were harvested at late exponential phase $\left(\mathrm{OD}_{560} 0.13\right.$ to 0.16 ) by centrifugation for $15 \mathrm{~min}$ at $8000 \mathrm{rpm}$ and room temperature. RNA extraction was performed by using the RNeasy Mini Kit (Qiagen, Hilden, NW, Germany) according to the manufacturer's instructions with some modifications. Cell lysis (after resuspension in RLT) was carried out by transferring the samples into FastPrep ${ }^{\circledR}$ tubes containing lysing beads-Matrix B (MP Biomedicals, Santa Ana, CA, USA) and disrupting them in a Fastprep instrument (FastPrep ${ }^{\circledR}-24$ Classic, MP Biomedicals, Santa Ana, CA, USA) for $40 \mathrm{~s}$ at $6 \mathrm{~m} / \mathrm{s}$. To remove possible DNA contamination, the RNA samples were treated twice with DNase I (RNase-Free Dnase kit, Qiagen, Hilden, NW, Germany) and then purified with the RNA Cleanup protocol (RNeasy Mini Kit, Qiagen, Hilden, NW, Germany) following manufacturer's instructions. RNA concentration was measured by using Quant-iT ${ }^{\mathrm{TM}}$ RiboGreen $^{\circledR}$ RNA Reagent and Kit (Invitrogen, Carlsbad, CA, USA) according to the manufacturer's instructions. To assess the quality of isolated RNA, the samples were loaded in an $1.2 \%$ agarose gel and measured in a Nanodrop (Nanodrop ND-1000 Spectrophotometer, Thermo Fisher Scientific, Waltham, MA, USA). The purified RNA samples were free of salt and phenol contamination. DNA contamination was additionally investigated by performing $16 \mathrm{~S}$ rRNA amplification from the RNA elutes (Section S2.2) and loaded in an $1.2 \%$ agarose gel. 
The purified RNA (150 ng) was subjected to cDNA synthesis by using an Ominiscript ${ }^{\circledR}$ Reverse Transcription Kit (Qiagen, Hilden, NW, Germany) with random hexamer primers according to manufacturer's instructions. A negative control without reverse transcriptase was prepared per sample. All samples were stored at $-20^{\circ} \mathrm{C}$ until usage (Section S2.3).

\subsection{Transcriptional Organization of bss, tdi, and bbs Gene Clusters by Reverse-Transcriptase PCR (RT-PCR)}

cDNAs of the intergenic regions of $b s s, t d i$, and $b b s$ genes as well as a fragment of the $x y l R$ transcript were prepared (Section S2.3) and PCR-amplified with the primers listed in Table 1. The amplification mixtures contained $1 \mu \mathrm{L}$ of cDNA, $6.25 \mu \mathrm{L}$ Red Taq $2 \times$ MasterMix (VWR, Darmstadt, HE, Germany), $0.5 \mu \mathrm{L}$ of each primer $\left(10 \mu \mathrm{M}\right.$ stock concentration), and $4.25 \mu \mathrm{L}$ of $\mathrm{dd}_{2} \mathrm{O}$. Amplification conditions were as follows: $2 \mathrm{~min}$ at $95^{\circ} \mathrm{C}$, followed by 30 cycles of annealing for $30 \mathrm{sec}$ at $60^{\circ} \mathrm{C}$, elongation for $30 \mathrm{sec}$ at $72{ }^{\circ} \mathrm{C}$ and denaturation for $30 \mathrm{sec}$ at $96^{\circ} \mathrm{C}$. Final elongation was done at $75^{\circ} \mathrm{C}$ for $5 \mathrm{~min}$.

Table 1. Primers used in this study.

\begin{tabular}{|c|c|c|c|c|}
\hline \multicolumn{5}{|c|}{ Primers Used for PCR } \\
\hline Target Sequence & Primer Name & Primer Sequence & $\begin{array}{l}\text { Product } \\
\text { Size (bp) }\end{array}$ & Source \\
\hline 16S rRNA & $\begin{array}{c}27 \mathrm{~F} \\
1492 \mathrm{R}\end{array}$ & $\begin{array}{l}\text { AGAGTTTGATCMTGGCTCAG } \\
\text { GGYTACCTTGTTACGACTT }\end{array}$ & 1465 & [31] \\
\hline$b s s A$ & $\begin{array}{l}\text { bssA_F1 } \\
\text { bssA_R2 }\end{array}$ & $\begin{array}{l}\text { GACGARTTCATCRTCGGCTACCACGC } \\
\text { AGCAGRTTGSCYTTCTGRTTYTTCTG }\end{array}$ & 1546 & Junca, $\mathrm{H}$. \\
\hline$b c r C$ & $\begin{array}{l}\text { bcrC_F } \\
\text { bcrC_R }\end{array}$ & $\begin{array}{l}\text { CGHATYCCRCGSTCGACCATCG } \\
\text { CGGATCGGCTGCATCTGGCC }\end{array}$ & 800 & [32] \\
\hline$b b s C$ region & bbsD_F bbsB_R & $\begin{array}{l}\text { GGCGGGATGTTGTCCTATGG } \\
\text { GCTTCGGCCCTATTTGCTTG }\end{array}$ & 1823 & this study \\
\hline \multicolumn{5}{|c|}{ Primers Used for RT-qPCR } \\
\hline Target Sequence & Primer Name & Primer Sequence & $\begin{array}{l}\text { Product } \\
\text { Size (bp) }\end{array}$ & Source \\
\hline 16S rRNA & $\begin{array}{l}\text { 16S_F } \\
16 \mathrm{~S} \_R\end{array}$ & $\begin{array}{l}\text { TGATGAAGGCCTTAGGGTTG } \\
\text { CCAGGGCTTTCACTTCTGAC }\end{array}$ & 170 & Marín, V. \\
\hline$b c r C$ & $\begin{array}{l}2 \mathrm{bcrC} C \mathrm{~F} \\
2 \mathrm{bcrC} \_\mathrm{R}\end{array}$ & $\begin{array}{l}\text { CATGATCTTCCCGTT } \\
\text { TCCTTCAGCTCCTTC }\end{array}$ & 159 & Marín, V. \\
\hline$b s s A$ & $\begin{array}{l}\text { bssA_F3 } \\
\text { bssA_R3 }\end{array}$ & $\begin{array}{l}\text { CGTCCTTCGCCTCGGGTTAC } \\
\text { CATCGCCTGCCAGTTGTCAATC }\end{array}$ & 188 & Marín, V. \\
\hline \multicolumn{5}{|c|}{ Primers Used for RT-PCR } \\
\hline Target Sequence & Primer Name & Primer Sequence & $\begin{array}{l}\text { Product } \\
\text { Size }(b p)\end{array}$ & Source \\
\hline $\begin{array}{l}\text { Intergenic region } \\
\quad b s s D-b s s A\end{array}$ & $\begin{array}{l}\text { bssD-bssA_F } \\
\text { bssD-bssA_R }\end{array}$ & $\begin{array}{l}\text { CGCATTCACATCCCGGTCATC } \\
\text { CAGGACGTTGGCGGTCATATT }\end{array}$ & 575 & this study \\
\hline $\begin{array}{l}\text { Intergenic region } \\
\quad b s s A-b s s E\end{array}$ & $\begin{array}{l}\text { bssA-bssE_F } \\
\text { bssA-bssE_R }\end{array}$ & $\begin{array}{l}\text { CTGAATTGCGACCTCTGAGC } \\
\text { GCTTGCGCGAGATATTACGG }\end{array}$ & 587 & this study \\
\hline $\begin{array}{l}\text { Intergenic region } \\
\quad b s s E-b s s F\end{array}$ & $\begin{array}{l}\text { bssE-bssF_F } \\
\text { bssE-bssF_R }\end{array}$ & $\begin{array}{l}\text { GGCAGGTCTGGATGGATGAG } \\
\text { CGTTTGGGAGGGGTATCGTC }\end{array}$ & 504 & this study \\
\hline $\begin{array}{l}\text { Intergenic region } \\
\quad b s s F-b s s G\end{array}$ & $\begin{array}{l}\text { bssF-bssG_F } \\
\text { bssF-bssG_R }\end{array}$ & $\begin{array}{l}\text { GCCATTCGCCGTTTCAACAA } \\
\text { GCGAACCTGGGAAAACATCG }\end{array}$ & 482 & this study \\
\hline $\begin{array}{l}\text { Intergenic region } \\
\quad b s s G-b s s P\end{array}$ & $\begin{array}{l}\text { bssG-bssP_F } \\
\text { bssG-bssP_R }\end{array}$ & $\begin{array}{l}\text { CCTTGGATGAAGGCCGTAAC } \\
\text { CCGAAGATCAGCCACTTTCC }\end{array}$ & 560 & this study \\
\hline $\begin{array}{l}\text { Intergenic region } \\
\quad b s s P-b s s I\end{array}$ & $\begin{array}{l}\text { bssP-bssI_F } \\
\text { bssP-bssI_R }\end{array}$ & $\begin{array}{l}\text { CCCGTTTCAAGCGATGGTTC } \\
\text { GAACTCCCTCCTTGCGGTAG }\end{array}$ & 493 & this study \\
\hline $\begin{array}{l}\text { Intergenic region } \\
\quad b s s I-b s s J\end{array}$ & $\begin{array}{l}\text { bssI-bssJ_F1 } \\
\text { bssI-bssJ_R1 }\end{array}$ & $\begin{array}{l}\text { CGAATTCCCCAGCGACTCA } \\
\text { ATCTCGAACACGCCCACTC }\end{array}$ & 561 & this study \\
\hline $\begin{array}{l}\text { Intergenic region } \\
\quad b s s J-b s s K\end{array}$ & $\begin{array}{l}\text { bssJ-bssK_F } \\
\text { bssJ-bssK_R }\end{array}$ & $\begin{array}{l}\text { GCCCCCTACTTCAAATGGCT } \\
\text { GTATCCCAATCCAGCGGAGG }\end{array}$ & 480 & this study \\
\hline $\begin{array}{l}\text { Intergenic region } \\
\quad b s s K-b s s L\end{array}$ & $\begin{array}{l}\text { bssK-bssL_F } \\
\text { bssK-bssL_R }\end{array}$ & $\begin{array}{l}\text { AGTTGATTTCCTACGGGCGG } \\
\text { GTGAGCAATCCACATGACGC }\end{array}$ & 515 & this study \\
\hline
\end{tabular}


Table 1. Cont.

\begin{tabular}{|c|c|c|c|c|}
\hline \multicolumn{5}{|c|}{ Primers Used for RT-qPCR } \\
\hline Target Sequence & Primer Name & Primer Sequence & $\begin{array}{l}\text { Product } \\
\text { Size (bp) }\end{array}$ & Source \\
\hline Intergenic region & tdiC-tdiR_F & GAGATCATGACGACGGAGGT & \multirow{2}{*}{500} & \multirow{2}{*}{ this study } \\
\hline tdiC-tdiR & tdiC-tdiR_R & TAGAAAGATCAGCGGCAGCG & & \\
\hline Intergenic region & tdiR-tdiS_F & CGCCTCAGCAAGGAAGTGTT & \multirow{2}{*}{435} & \multirow{2}{*}{ this study } \\
\hline tdiR-tdiS & tdiR-tdis_R & GGAAGCAAATGCCAACGGG & & \\
\hline & xylR_F & TGTCGAGCGTGGCTATTACTC & \multirow{2}{*}{545} & \multirow{2}{*}{ this study } \\
\hline$x y l R$ & xylR_R & CTTCCACCAAATTCTCGGGC & & \\
\hline Intergenic region & bbsA-bbsB_F & GGGCAGCTTGATTTTCCCAA & \multirow{2}{*}{436} & \multirow{2}{*}{ this study } \\
\hline$b b s A-b b s B$ & bbsA-bbsB_R & GGCGATGAACACATCTCGTTG & & \\
\hline Intergenic region & bbsB-bbsC_F & GGCGGGATGTTGTCCTATGG & \multirow{2}{*}{535} & \multirow{2}{*}{ this study } \\
\hline$b b s B-b b s C$ & bbsB-bbsC_R & ACCGATTCCGGAAGGAAAGG & & \\
\hline Intergenic region & bbsC-bbsD_F & CGGCAAGAGCGCCTATTTCT & \multirow[b]{2}{*}{611} & \multirow[b]{2}{*}{ this study } \\
\hline$b b s C-b b s D$ & bbsC-bbsD_R & GGTGATTCCATTGCGTCCCA & & \\
\hline Intergenic region & bbsD-bbsE_F & CTGGGACGCAATGGAATCAC & \multirow{2}{*}{542} & \multirow{2}{*}{ this study } \\
\hline$b b s D-b b s E$ & bbsD-bbsE_R & GCGCAAAAACACCTCCCTG & & \\
\hline Intergenic region & bbsE-bbsF_F1 & ATACGCCTATCGGACCTCGG & \multirow{2}{*}{380} & \multirow{2}{*}{ this study } \\
\hline$b b s E-b b s F$ & bbsE-bbsF_R1 & GCTCTGCATGAACCACTTCC & & \\
\hline Intergenic region & bbsF-bbsG_F & CGCGGTGTTTTCCGATGAAG & \multirow{2}{*}{550} & \multirow{2}{*}{ this study } \\
\hline$b b s F-b b s G$ & bbsF-bbsG_R & TTCAGCATTGCGTGCTCTTG & & \\
\hline Intergenic region & bbsG-bbsH_F & CGGGAAACCGGCATCGAATA & \multirow{2}{*}{428} & \multirow{2}{*}{ this study } \\
\hline bbsG-bbsH & bbsG-bbsH_R & TTCATCTGGGGGATGAGGGG & & \\
\hline
\end{tabular}

\subsection{Gene Expression Assessment by Quantitative RT-PCR (qRT-PCR)}

The quantification of $b s s A$ and $b c r C$ gene expression in anoxic and oxic conditions was carried out by using the primer pairs bssA_F3/bssA_R3 and 2bcrC_F/2bcrC_R. These primer pairs annealed to intergenic sections of the $b s s A$ and $b c r C$ genes, respectively (Table 1). Amplification conditions were the following: $2 \mathrm{~min}$ at $95^{\circ} \mathrm{C}, 40$ cycles of annealing for $20 \mathrm{sec}$ at $58^{\circ} \mathrm{C}(b s s A), 62^{\circ} \mathrm{C}(b c r C)$ and $56{ }^{\circ} \mathrm{C}$ (16s rRNA). Elongation was carried out for $20 \mathrm{sec}$ at $72{ }^{\circ} \mathrm{C}$ and denaturation for $3 \mathrm{sec}$ at $95^{\circ} \mathrm{C}$. Final elongation was done at $75^{\circ} \mathrm{C}$ for $5 \mathrm{~min}$. For the normalization of $b s s A$ and $b c r C$ transcripts in each sample, 16S rRNA copy numbers were recorded after qRT-PCR by using the primer pair 16S_F/16S_R. The quantification was performed in a 96-well Microtiter microplate on a Step One Plus Real Time PCR System (Applied Biosystems, Thermo Fischer Scientific, Waltham, MA, USA) using the KAPA SYBR Fast master mix (Section S2.5). In the wells, standards and cDNA samples were prepared and measured in triplicate. A negative control (template without RT) per sample was also included. The standards were serially diluted, and the cDNA samples were either undiluted or diluted 1:10 depending on the experimental conditions (Section S2.5).

Quantification was performed by calculating the abundance of $b s s A$ and $b c r C$ transcripts from their corresponding standard curves (Section S2.4). Normalization was carried out by using $16 \mathrm{~S}$ rRNA copy numbers as the calibrator. Fold changes were further calculated by using the expression of $b s s A$ and $b c r C$ from benzoate-grown cells as the reference (Section S2.6).

\subsection{Protein Extraction and Preparation}

For protein extraction, $25 \mathrm{~mL}$ of culture was harvested in late exponential phase ( $\mathrm{OD}_{560} 0.13$ to 0.16 ) and centrifuged for $10 \mathrm{~min}$ at $8000 \mathrm{rpm}$. The pellets were then resuspended in $500 \mu \mathrm{L}$ of Urea buffer $(8 \mathrm{M}$ urea and $2 \mathrm{M}$ thiourea) and transferred to FastPrep tubes containing $0.1 \mathrm{~mm}$ zirconia and $2.85-3.45 \mathrm{~mm}$ glass beads (Carl Roth, Karlsruhe, BW, Germany). The cells were lysed in a FastPrep device for $40 \mathrm{~s}$ at $5 \mathrm{~m} / \mathrm{s}$. (FastPrep ${ }^{\circledR}-24$ Classic, MP Biomedicals, Santa Ana, CA, USA) and by sonication on ice twice at $70 \%$ power $(25 \mathrm{~W})$ and $70 \%$ duty cycle (UP50H, Hielscher Ultrasonic, Teltow, BB, Germany).

The total amount of protein was quantified by the Bradford method as described before [33]. Then, $60 \mu \mathrm{g}$ of proteins from the supernatants were precipitated with a 5 -fold volume of acetone $(100 \%)$ and incubated overnight $\mathrm{a}-20^{\circ} \mathrm{C}$. After incubation, the protein pellets were precipitated by centrifugation 
(14,000 rpm for $10 \mathrm{~min}$ ) and air-dried in a vacuum concentrator (Eppendorf, Hamburg, HH, Germany) for $5 \mathrm{~min}$. Protein separation, staining and proteolytic cleavage was performed as described before [34]. Peptide lysate desalting was performed using SOLA $\mu$ HRP 96-well plates (Thermo Fischer Scientific, Waltham, MA, USA) by applying different concentrations of acetonitrile and formic acid. Prior to LC-MS/MS measurement, proteotypic peptide samples were quantified via NanoDrop (NanoDrop 2000C, Thermo Fischer Scientific, Waltham, MA, USA).

\subsection{LC-MS/MS and Proteome Analysis}

The samples were injected into a Nano-HPLC (Ultimate nanoRSLC 3000, Thermo Fischer Scientific, Waltham, MA, USA) and proteotypic peptides lysates were separated with a C18-reverse phase analytical column (Acclaim PepMap ${ }^{\circledR}$ 100, $75 \mu \mathrm{m} \times 25 \mathrm{~cm}$, particle size $3 \mu \mathrm{M}$, nanoViper, Thermo Fisher Scientific, Waltham, MA, USA) in a two-step LC gradient. The eluting peptide lysates were ionized by a nano-ion source (TriVersa Nanomate, Advion, Ithaca, NY, USA) and measured using a Q Exactive HF mass spectrometer (Thermo Fisher Scientific, Waltham, MA, USA) with the setup described in the Supplemental Material Section S2.7.

The raw LC-MS/MS data were analysed using Proteome Discoverer v. 2.2 (Thermo Fischer Scientific, Waltham, MA, USA) with the following parameters: oxidation for dynamic modifications, carbamidomethylation for static modifications, MS tolerance $10 \mathrm{ppm}, \mathrm{MS} / \mathrm{MS}$ tolerance $0.02 \mathrm{Da}$, trypsin (set as full specific) and two missed cleavage sides. Database search was performed using Sequest HT algorithm against the annotated protein-coding sequence database of Magnetospirillum sp. 15-1 [28] from RAST [35-37]. Only peptides with a false discovery rate (FDR) $<1 \%$ calculated by Percolator [38] were considered as identified. Identified proteins were grouped by applying the strict parsimony principle, in which protein hits are reported as the minimum set that accounts for all observable peptides. Protein abundances were then calculated based on the top3 approach implemented in Proteome Discoverer v. 2.2 and normalization of the peptides were manually performed as described before $[39,40]$. Proteome fold changes of toluene-grown cells were calculated relative to benzoate-grown cells, for aerobic and anaerobic conditions separately as shown in Table S3 and as described in the Section S2.8. Venn diagrams were generated using the Venn Diagram Plotter [41]. Functional proteome analysis was performed using GHOSTKOALA [42] and IPath [43,44]. MeV [45] was used for hierarchical clustering.

\subsection{Data Availability}

The qPCR and proteomic raw data have been deposited in Figshare [46]. Data sets S1 [47], S2 [48] and S3 [49] are included.

\section{Results}

\subsection{Genomic Organization of Genes Involved in Anaerobic Toluene Transformation}

It was previously hypothesized that horizontal gene transfer events of bss genes had occurred among denitrifiers [15,16]. The closely related strains 15-1 and TS-6 [23] are the only known carriers of $b s s$ and $b b s$ genes within the alphaproteobacterial genus Magnetospirillum. These two strains group phylogenetically with the non-toluene-degrading M. magnetotacticum and M. magneticum $[23,28,29]$. Thus, it is most parsimonious to assume that an ancestor of strains 15-1 and TS-6 acquired horizontally the genes needed for anaerobic toluene degradation. The analysis of sequence composition indicated that the $b s s$ and $b b s$ genes of strain 15-1 share a common ancestor with those of various toluene-degrading Azoarcus sp.and Aromatoleum spp. isolates and the uncultivated Herminiimonas sp. CN [50]. The gene content of the bss cluster is similar in strain 15-1, Azoarcus sp. CIB, Aromatoleum tolulyticus ATCC 51758, and Aromatoleum toluclasticus ATCC 700605 except for a gene, $b s s P$, which is unique to Magnetospirillum sp. 15-1. The bssP gene is located between bssI and bssJ in strain 15-1 and is predicted to encode a small protein of unknown function (Figure 1). Amino acid identities of BssA and BssE ranged from 79 
to $86 \%$ between strain $15-1$ and the denitrifiers mentioned above (Table S1). Identities of the other predicted proteins coded by the bss genes ranged from 48 to $76 \%$ between strain $15-1$ and the respective closest relative. The $b b s$ genes needed for the transformation of benzylsuccinate into benzoyl-CoA are present in all denitrifying toluene degraders except for $b b s J$ and $b b s I$, which are of unknown function and are absent in several strains including 15-1. Identities of the Bbs proteins ranged from 73 to $84 \%$ between strain 15-1, Azoarcus sp. CIB, and Herminiimonas sp. CN except for BbsC, which shared at most only $45 \%$ amino acid sequence identity between strain $15-1$ and the other strains (confirmed by Sanger sequencing on the nucleic acid level). Identities of TdiS and TdiR were around $60 \%$ between strain 15-1 and Herminiimonas sp. CN, the host of their closest homologs. Among the TdiS homologs most of the sequence divergence was in the second PAS/PAC domain (involved in dimerization) of the protein $[16,51]$ while TdiR divergence was more evenly distributed over the entire sequence length (Figure S2). The GC\% of the bss cluster (62.8\%) is slightly lower than that of the bbs cluster $(65.2 \%)$ and the whole genome $(65.6 \%)$ of strain $15-1$.

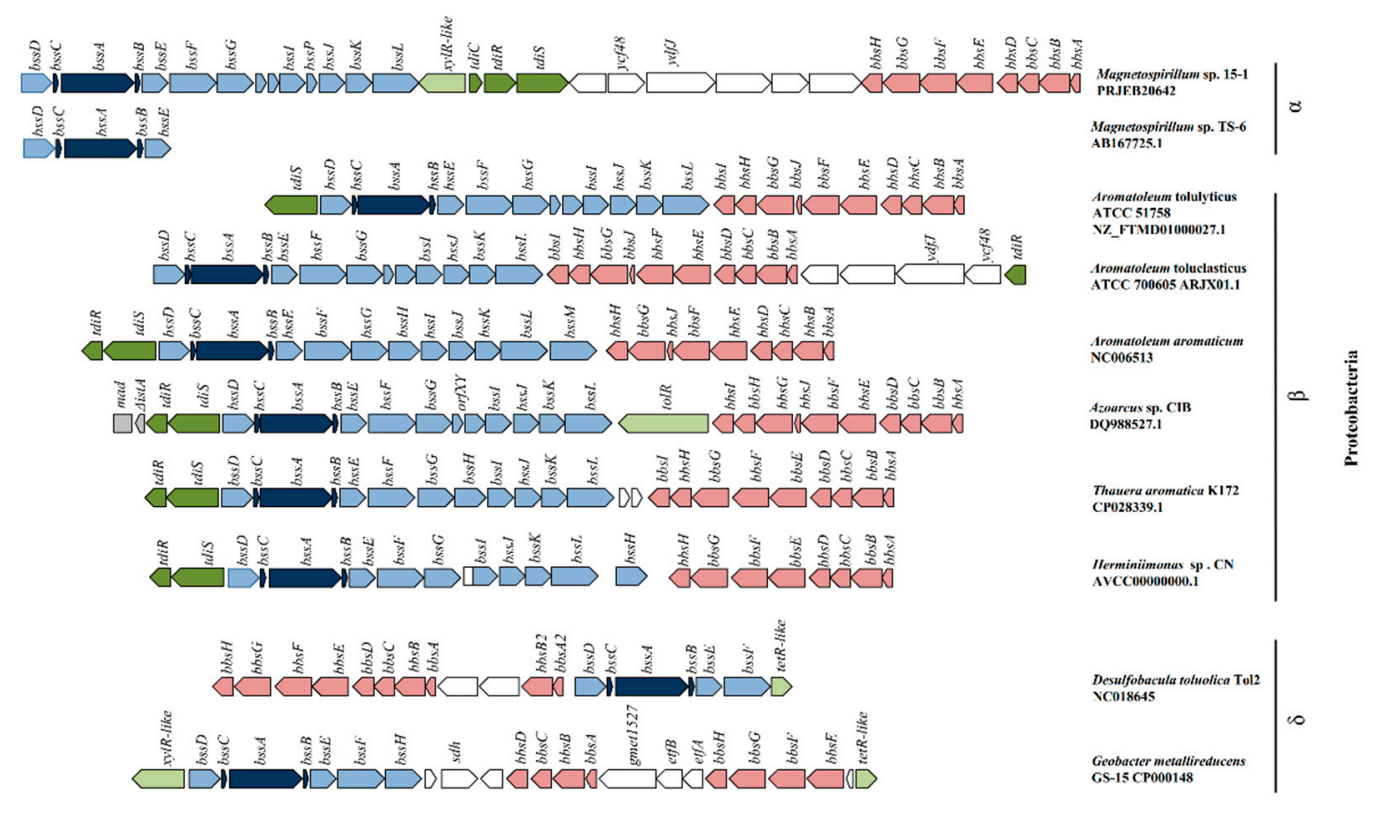

Figure 1. Organization and comparison of the $b s s-b b s$ gene region in selected bacteria capable of anaerobic toluene degradation. Genes are represented by arrows: 'dark blue' for $b s s A B C$; 'light blue' for accessory bss genes; 'pink' for genes needed for transformation of benzylsuccinate to benzoyl-CoA; 'olive' for $t$ di genes; 'light green' for putative regulator-coding genes; 'white' for remaining genes without evidence for involvement in anaerobic toluene degradation. The gene names are as follows: $b s s A B C$ and $b s s D$ subunits code for a benzylsuccinate synthase and its corresponding activase, respectively; $b s s E$, putative chaperone; $b s s G-J$ and $b s s L$, unknown function; $b s s K$, mRNA binding protein; $x y l R, \sigma^{54}$-dependent regulator, $t d i C$, regulator of TdiR activity; $t d i R$, toluene degradation regulator; $t$ diS, toluene degradation inducing sensor; $b b s E F$, (3-methyl) benzylsuccinate CoA transferase; $b b s G$, (3-methyl) benzylsuccinyl-CoA dehydrogenase; $b b s H$, (3-methyl) phenylitaconyl-CoA hydratase; $b b s C D$, 2-[hydroxyphenyl(methyl)]-succinyl-CoA dehydrogenase; $b b s A B$, BbsAB, (3-methyl) benzoylsuccinyl-CoA thiolase.

There are a few differences between strain 15-1 and all other sequenced denitrifying toluene degraders at this genomic locus. In strain 15-1, the $t d i$ genes are located between the $b s s$ and $b b s$ genes rather than upstream of $b s s D$, they are in reverse order, and $21 \mathrm{bp}$ upstream of $t d i R$ is a gene predicted to encode a protein of 149 amino acid residues with a cystathionine-beta-synthase (CBS) domain. CBS domains may play a regulatory role via making proteins sensitive to adenosyl carrying ligands such as AMP, ATP and S-AdoMet [52]. Protein alignment by BLAST revealed that close homologues to the gene in strain 15-1 are present at various genomic loci in all sequenced Magnetospirillum strains 
and other Alphaproteobacteria, in particular in strains isolated from rhizospheres, but not in other Proteobacteria (data not shown). Between the CBS domain-encoding gene and the bss cluster is a gene predicted to encode a $\sigma^{54}$-dependent $\mathrm{NtrC} / \mathrm{XylR}$-type transcriptional regulator with around $42 \%$ amino acid sequence identity with a protein coded adjacent to the bss gene locus in toluene-degrading Geobactereaceae. The various genetic arrangements show on one side congruity among denitrifying toluene degraders concerning basic features and some regulatory aspects of benzylsuccinate generation and its transformation into benzoyl-CoA, but indicate also that these mosaic genetic structures result in strain-specific differences in regulation, enzyme assembly, and even catalysis [53].

\subsection{Regulation of bss Gene Expression in Magnetospirillum sp. Strain 15-1}

The transcriptional organization of the $b s s, t d i$ and $b b s$ genes was investigated by RT-PCR with RNA isolated from toluene-grown cells (Figure S3, primer sequences provided in Table 1).

RT-PCR products of the expected sizes were obtained for all intergenic regions of the $b s s$ and $b b s$ cluster, demonstrating that these genes form two polycistronic units. Likewise, the gene encoding a CBS domain protein was co-transcribed with $t$ diSR. We name this novel gene $t d i C$ and propose that its product is involved in modulating the activity of TdiR.

The previously proposed regulatory DNA sequence (ARGTGTYCGCACC) [16] was found $121 \mathrm{bp}$ and 109 bp upstream of the predicted starts of $b s s D$ and $b b s A$, respectively, suggesting that the $b s s$ and $b b s$ genes are co-regulated in strain 15-1. To identify environmental parameters that play a role in the regulation of expression of these genes in strain 15-1, we calculated fold changes after RT-qPCR quantification from total RNA isolated from cultures grown under aerobic and anaerobic conditions, in the presence of toluene and benzoate, and various concentrations of nitrate (Data Set S1 and S2). The expression of benzoyl-CoA reductase was recorded as reference by measuring the $b c r C$ gene.

In cells growing aerobically on benzoate, the addition of toluene induced $b s s A$ expression by about 20-fold (Figure 2). This result corresponded to the high $b s s A$ transcript levels in the oxic PFRs [27,34]. The range of anaerobic $b s s A$ induction was queried for via differential comparison of cultures grown either with toluene or with benzoate as carbon and electron donor. There was an induction of $b s s A$ by 119-fold in toluene-grown cells relative to benzoate-grown cells (Figure 2). This further increase in gene expression as compared to the effect of toluene alone was likely triggered by the absence of molecular oxygen. This signal may potentially be sensed directly via an FNR-type scheme (regulator of fumarate and nitrate reduction) as with the well-studied GRE formate C-acetyltransferase (pyruvate formate lyase) [54,55], or indirectly via benzylsuccinate formation as proposed effector for the Tdi regulatory system $[16,21]$, or via the presence of nitrate detected by sensors-regulators such as NarXL and NarQP [56-59].

To further illuminate the question of sensory input we searched for potential regulatory components in the draft genome of strain 15-1. We identified 12 genes coding for members of the CRP/FNR superfamily (Table S2) and at least 10 two-component regulatory systems where the response regulator belongs to the NarL/FixJ family. The canonical binding motifs for FNR [60] and for the sensor-regulator system NarP/NarL $[58,61]$ were not detected in the upstream regions of the $b s s$ and $b b s$ genes. Yet the FNR binding motif was found only 4 times in the genome of strain 15-1, and those hits were not located next to classical genes of the FNR regulon such as nar and nir genes [62], indicating a deviation from the consensus binding sequence in this strain. Binding motives for NarL/NarP were found upstream of nar genes. Thus, there was no genomic evidence for an involvement of nitrate-sensing in $b s s$ and $b b s$ expression, while sequence analyses were inconclusive in regard to a regulatory mechanism encompassing oxygen-sensing by an FNR-like scheme.

To test experimentally whether nitrate induces bss $A$ expression, strain 15-1 was cultivated under anoxic conditions with toluene and benzoate at various concentrations of nitrate $(2.5,5$, and $10 \mathrm{mM})$. In addition, we calculated $b s s A$ fold changes from cultures grown aerobically with benzoate in the co-presence of $5 \mathrm{mM}$ nitrate and $0.3 \mathrm{mM}$ toluene (Figure 2). Under anoxic conditions, the growth rate with $2.5 \mathrm{mM}$ and $5 \mathrm{Mm}$ nitrate were $0.05 \mathrm{~h}^{-1}$ and $0.07 \mathrm{~h}^{-1}$ respectively, while with $10 \mathrm{mM}$ 
nitrate the growth rate was reduced to $0.02 \mathrm{~h}^{-1}$. Nitrite was never detected in any of those cultures (limit of detection: $21 \mu \mathrm{M}$ ). The relative abundance of $b s s A$ transcripts in toluene-grown cultures versus benzoate-grown cultures with $2.5 \mathrm{mM}$ nitrate was similar (129-fold induction) to that with $5 \mathrm{mM}$ nitrate (119-fold induction). In contrast, with $10 \mathrm{mM}$ nitrate the $b s s A$ gene was induced only 7-fold in cells grown anaerobically with toluene. The level of $b c r C$ transcription was rather similar at the various nitrate concentrations in both anaerobically- and aerobically-grown cells (Figure S4). In aerobically-grown cultures, the level of $b s s A$ induction was even lower in the presence of nitrate than without it (Figure 2). Thus, our data support that nitrate-sensing is unlikely to be involved in up-regulation of bss expression.

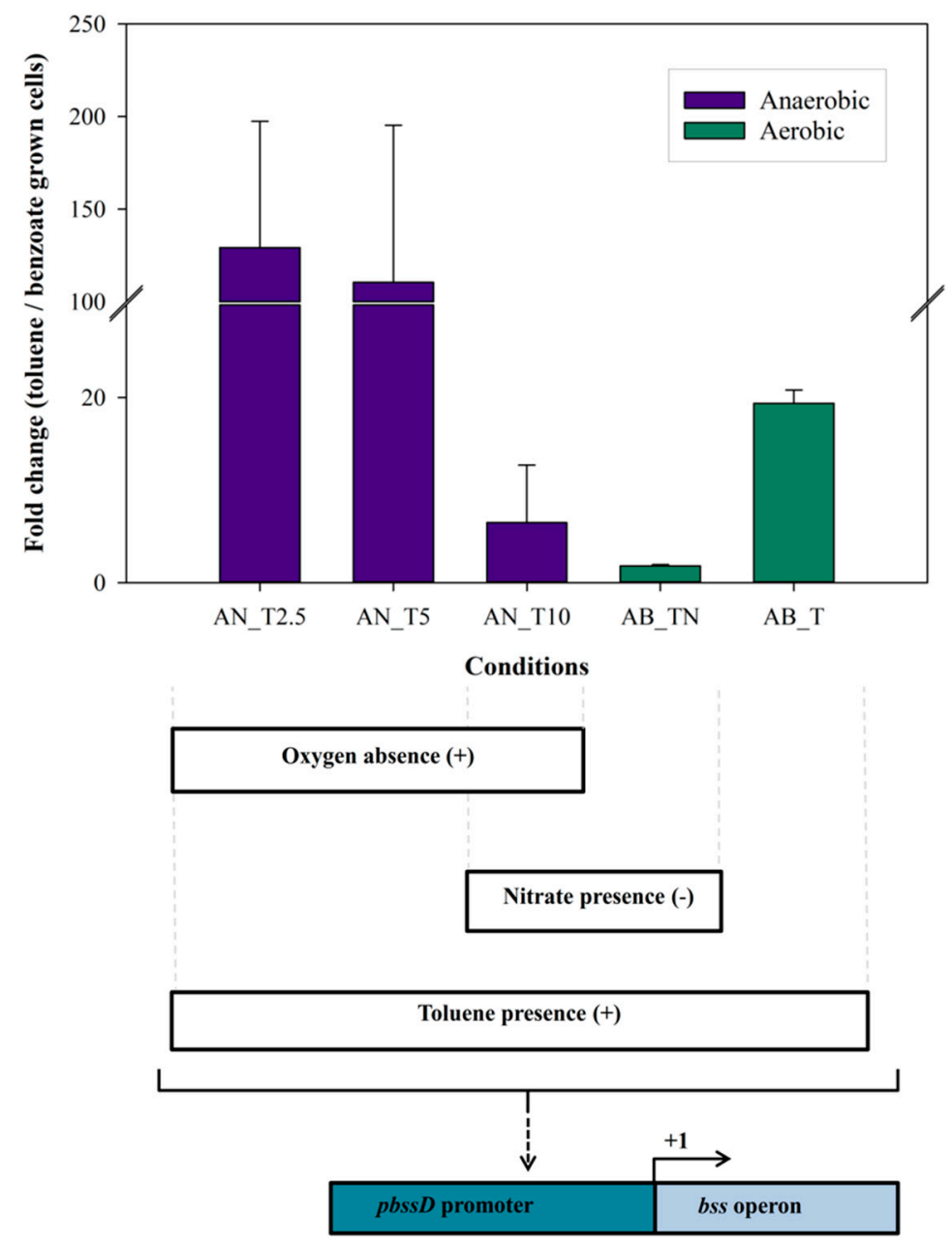

Figure 2. bssA expression in anaerobic and aerobic cultures of Magnetospirillum sp. 15-1. AN_T represents cultures growing anaerobically with toluene and either $2.5 \mathrm{mM}$ (AN_T2.5), 5 mM (AN_T5), or $10 \mathrm{mM}\left(\mathrm{AN} \_\mathrm{T} 10\right)$ of $\mathrm{KNO}_{3}$. AB_T represents cultures growing aerobically with benzoate and supplied additionally with either toluene alone $\left(\mathrm{AB}_{-} \mathrm{T}\right)$ or toluene and $5 \mathrm{mM}$ of $\mathrm{KNO}_{3}\left(\mathrm{AB}_{-} \mathrm{TN}\right)$. The promoter ( $p b s s D$ of the bss operon) and the initiation of its transcription $(+1)$ could be induced $(+)$ or repressed (-) due to the presence of oxygen, nitrate, and toluene.

\subsection{Proteins Involved in Anaerobic Toluene Degradation}

Next, we measured the proteomes based on peptide identification of strain 15-1 grown under the same conditions as in the experiments targeting gene expression. The genome of strain 15-1 harbors 5,095 predicted coding sequences (CDS). In total, 2,459 unique protein groups were identified where 59\% were detected under both anoxic and oxic conditions (Figure 3a, Data set S3). The proteome coverage is similar to that of Escherichia coli under 22 experimental conditions [63]. A hierarchical clustering 
dendrogram based on protein $\log _{2}$ fold-changes showed the expected topology with branches for the anaerobic and the aerobic cultures (Figure 3b). KEGG pathway mapping revealed only few differences between anoxic and oxic conditions (Figure S5). Besides the proteins of the toluene degradation pathway, proteins which were exclusively detectedin anaerobically-grown cells were involved in environmental sensing, flagellum synthesis, transport processes across the membrane, transcription, translation, and folate metabolism.

a

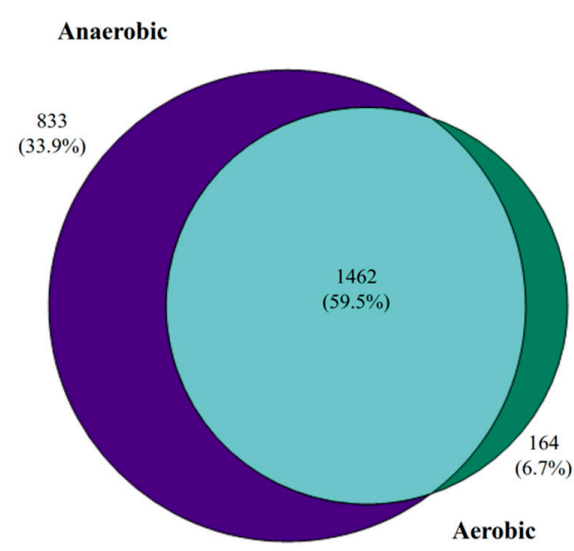

b

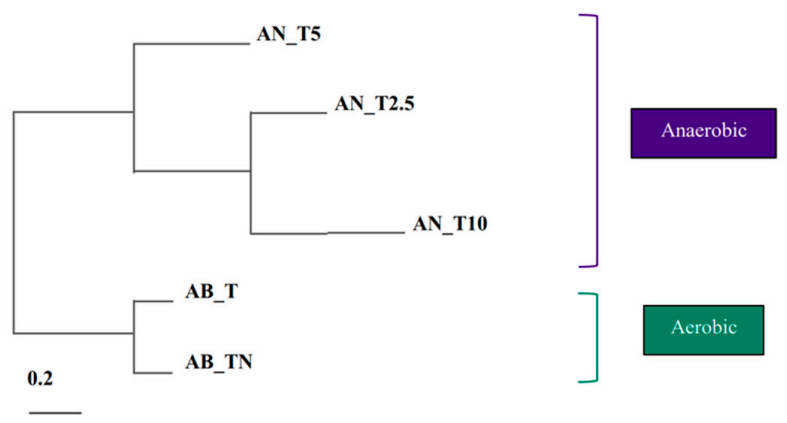

Figure 3. Proteome changes in response to oxygen and nitrate. Total and shared proteins (a) and hierarchical clustering of proteome profiles (b) among oxic and anoxic conditions with different nitrate concentrations are shown. AN_T represents cultures growing anaerobically with toluene and either $2.5 \mathrm{mM}$ (AN_T2.5), $5 \mathrm{mM}$ (AN_T5), or $10 \mathrm{mM}$ (AN_T10) of $\mathrm{KNO}_{3}$. AB_T represents cultures growing aerobically with benzoate and supplied additionally with either toluene alone $\left(\mathrm{AB}_{-} \mathrm{T}\right)$ or toluene and $5 \mathrm{mM}$ of $\mathrm{KNO}_{3}\left(\mathrm{AB} \_\mathrm{TN}\right)$.

Under nitrate-reducing conditions with toluene as growth substrate, all proteins known to be needed for transformation of toluene into benzoyl-CoA, except for BssP, were detected (Figure 4). In comparison with the corresponding benzoate-grown cells, BssA ranked almost always among the proteins with the highest fold change ( $\log _{2}$-fold range of 5.9 to $8.1, p$-value $<0.05$ ). The exception was the cultivation with $5 \mathrm{mM}$ nitrate, were no BssA fold change could be calculated because the protein could not be reliably measured in benzoate grown cells. For all other $b s s$ gene products, the protein abundance was at least $1.7 \log _{2}$-fold higher (range $1.7-6.4 \log _{2}$-fold, $p$-value $<0.05$ ) in toluene-grown versus benzoate-grown cells. The protein abundances of the 5 Bbs enzymes were $2.38-5.3 \log _{2}$-fold increased ( $p$-values $<0.05$ ) in toluene-grown cells as compared to benzoate-grown cells. Proteins needed for the anaerobic transformation of benzoyl-CoA were detected in cells grown under all anoxic conditions with comparably small differences between toluene-grown and benzoate-grown cells. 


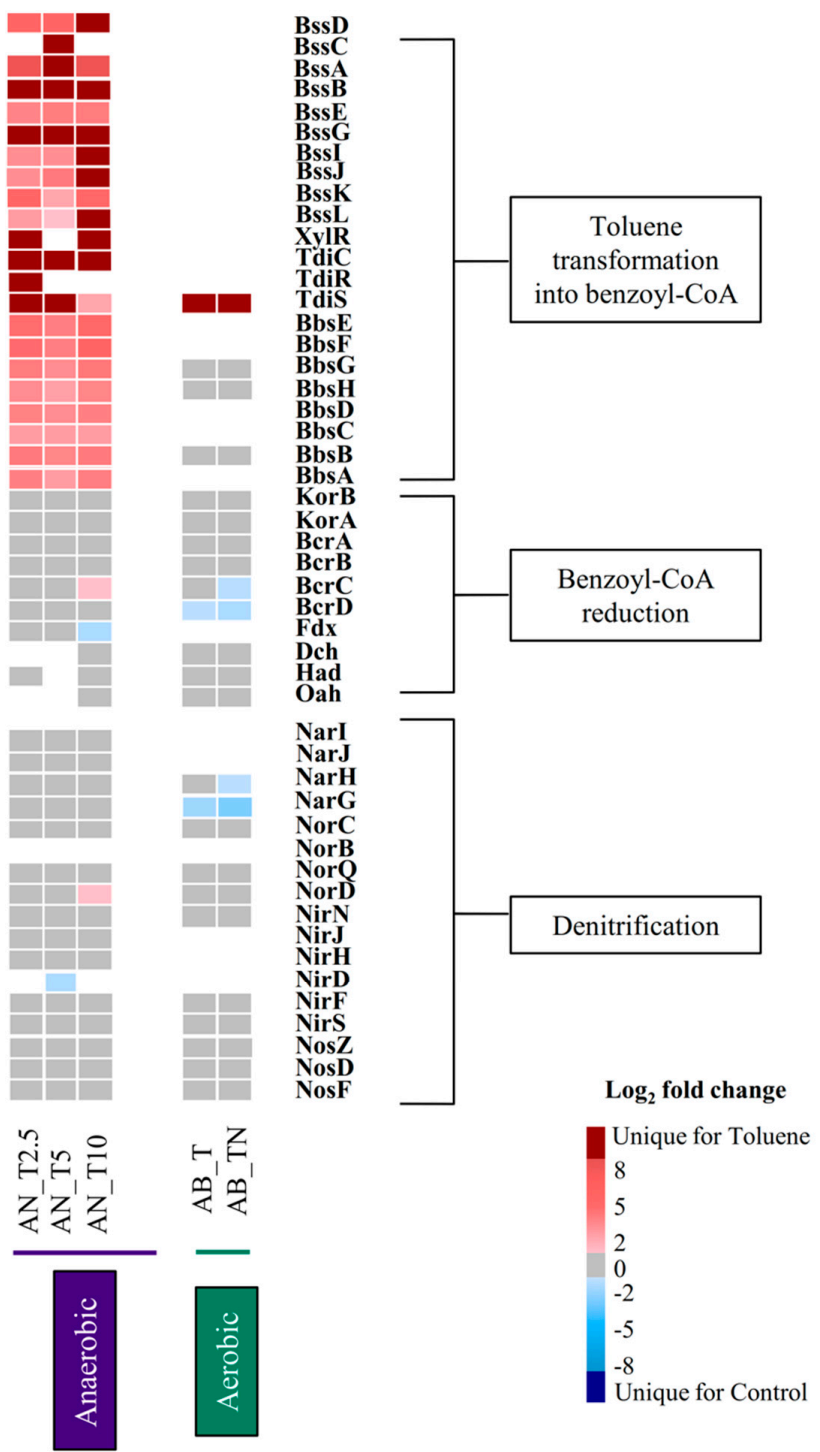

Figure 4. Heatmap visualization of protein regulation required for toluene and benzoate degradation pathways in anaerobic denitrifying and aerobic cultures of Magnetospirillum sp. 15-1. Up-regulated proteins are represented by $n \geq 1$ and are coloured in shades of red. Down-regulated proteins are represented by $n \leq-1$ and are coloured in shades of blue. AN_T represents cultures growing anaerobically with toluene and either $2.5 \mathrm{mM}$ (AN_T2.5), $5 \mathrm{mM}$ (AN_T5), or $10 \mathrm{mM}$ (AN_T10) of $\mathrm{KNO}_{3} . \mathrm{AB} \_\mathrm{T}$ represents cultures growing aerobically with benzoate and supplied additionally with either toluene alone $\left(\mathrm{AB} \_\mathrm{T}\right)$ or toluene and $5 \mathrm{mM}$ of $\mathrm{KNO}_{3}\left(\mathrm{AB} \_\mathrm{TN}\right)$. BssD, benzylsuccinate activating enzyme; BssABC, benzylsuccinate synthase; BssE, putative chaperone; BssG-J and BssL, unknown function; BssK, mRNA binding protein; XylR, $\sigma^{54}$-dependent regulator, TdiC, regulator of TdiR activity; TdiR, toluene degradation regulator; TdiS, toluene degradation inducing sensor; BbsEF, (3-methyl)benzylsuccinate CoA transferase; BbsG, (3-methyl)benzylsuccinyl-CoA dehydrogenase; $\mathrm{BbsH}$, (3-methyl)phenylitaconyl-CoA hydratase; BbsCD, 2-[hydroxyphenyl(methyl)]-succinyl-CoA dehydrogenase; BbsAB, (3-methyl)benzoylsuccinyl-CoA thiolase; BclA, benzoate-CoA ligase; KorBA, 2-oxoglutarate oxidoreductase; BcrABCD, benzoyl-CoA reductase; Fdx, 4Fe-4S ferredoxin; Dch, dienoyl-CoA hydratase; Had, 6-hydroxycyclohex-1-ene-1-carboxyl-CoA dehydrogenase; Oah, 6-oxocyclohex-1-enecarboxyl-CoA hydrolase; NarGHI, nitrate reductase; NarJ protein assembly; NorCB, nitric oxide reductase; NorQ and NorD, unknown function; NirN, haem d1 insertion protein; NirJHLD, unknown functions; NirF, membrane attached lipoprotein; NirS, nitrite reductase; NosZ, nitrous oxide reductase; NosD, putative $\mathrm{Cu}$ insertase; NosF, ATP-hydrolyzing of ABC transporters. 
Under oxic conditions, no bss gene product could be identified. Among the enzymes needed for converting benzylsuccinate into benzoyl-CoA, only BbsB and BbsG were detected at low abundances. In contrast, most proteins of the benzoyl-CoA pathway were found, although their abundances were low (Data set S3). These results matched the observed protein occurrences in the PFRs [27,34]. The substantial bss $A$ induction without concomitant detection of the otherwise abundant protein provides strong evidence for post-transcriptional regulation of BSS in strain 15-1 under oxic conditions.

\subsection{Expression Pattern of the Transcriptional Regulatory Components TdiCRS and XylR}

In Azoarcus sp. CIB, the Tdi two-component regulatory system controls expression of the bss and $b b s$ cluster as well as its own genes [16]. In cells of strain 15-1 grown anaerobically on toluene and with $2.5 \mathrm{mM}$ nitrate, TdiC, TdiS, and TdiR were detected. With nitrate concentrations of $5 \mathrm{mM}$ and $10 \mathrm{mM}, \mathrm{TdiC}$ and TdiS but not TdiR were found in toluene-grown cells (Figure 4). Only low cellular copy numbers of TdiR are likely to be needed for effective regulation (Leuthner and Heider, 1998), which may explain why the protein was not detected in these samples. TdiC and TdiR were not found in any other condition than during anaerobic growth with toluene, while TdiS was also detected in cells grown anaerobically on benzoate or aerobically in the presence of toluene. These findings indicate that synthesis level of TdiCRS in strain 15-1 depends on the presence of toluene (or benzylsuccinate) and apparently also on anoxic conditions, which in turn might affect expression levels of the $b s s$ and $b b s$ genes.

The NtrC/XylR-type transcriptional regulator was detected only in cells grown under anoxic conditions on toluene. It remains to be shown whether this protein has any regulatory effect on $b s s$ and $b b s$ gene expression in strain 15-1.

\subsection{Proteins Involved in the Denitrification Process}

Most denitrification protein abundances remained unchanged among the various anaerobic cultures (Figure 4). Only the catalytically active subunit of nitric oxide reductase, NorB, was infrequently detected probably due to its integral membrane protein nature [64]. Under oxic conditions, the majority of proteins involved in denitrification were present too, albeit down-regulated by -0.99 to $-2.74 \log _{2}$-fold relative to benzoate-grown cells. The presence of these proteins under oxic conditions matched the previous finding of denitrification occurring in the PFRs [27].

\section{Discussion}

For microbes capable of anaerobic toluene degradation and living in habitats in which anoxic and oxic conditions frequently alternate, the regulatory decision to synthesize BSS is not trivial [13]. The active enzyme is rapidly and irreversibly destroyed by molecular oxygen. Even if a radical quenching mechanism of the active form into the inactive one by, e.g., a small diffusible molecule would be in place $[65,66]$, it is unlikely that such a mechanism would be faster at all times than molecular oxygen reaching the radical site of BSS. In addition, there is evidence for oxygen sensitivity of BssB and BssC [14,15]. Furthermore, BSS is a kinetically slow enzyme. In Thauera aromatica growing on toluene it makes up several percent of the soluble protein content of the cell [67]. Thus, the timing and strength of BSS synthesis would ideally be tuned according to the dynamics of the ambient conditions in order to prevent that the cell is burdened with too much unusable or even destroyed enzyme. A respective regulatory scheme would need to process multiple sensory inputs from environmental and cellular clues.

In this study we present novel insights into the complex regulation of BSS expression in Magnetospirillum sp. strain 15-1. Firstly, and the key finding of this study, the synthesis of BSS is under post-transcriptional regulation in this strain. This novel type of regulation for the GRE family constitutes a bacterial decision gateway, allowing for a quick adaptation process to conditions in the ambient ecosystem that are amenable for anaerobic toluene degradation. Post-transcriptional regulators can be RNA binding proteins (RBP), ribonucleases, helicases, or small RNA molecules [68-71], all of 
which can modulate mRNA stability or the initiation of translation. They may act on a global transcriptome level or be restricted to a small set of transcripts. We assume that the stringently controlled translation of the bss gene products is governed by a specific regulatory scheme rather than by a global translational regulator involved in the transition between aerobic and anaerobic growth. A candidate regulator is BssK, which is encoded in the bss gene cluster in all sequenced denitrifying and some sulfate-reducing bacteria capable of anaerobic toluene degradation. BssK is a member of the short-chain dehydrogenases/reductases (SDR) superfamily [72]. The widely distributed SDR protein fold is adaptable to diverse functions including mRNA binding and RNase activity [73,74]. BssK belongs to the atypical subgroup 1, which members lack the canonical active site residues of SDR enzymes with dehydrogenase/reductase function [72]. Some of the subgroup 1 proteins are postulated to be involved in redox sensing [75]. The detection of BssK exclusively under anoxic conditions suggests that this protein acts as a translational activator in the absence of oxygen. Considering that this strain's capability to degrade toluene anaerobically is likely the result of horizontal gene transfer, this regulatory feature could be common among denitrifying toluene degraders.

Secondly, the bss genes are transcribed already under oxic conditions in strain 15-1, and the transcription increases further in the absence of oxygen. The expression of $b s s A$ under oxic conditions is congruent with its comparably high expression level in the PFRs [27,34]. Similarly, in the facultative anaerobe Thauera sp. strain DNT-1 approximately equal levels of $b s s A$ transcripts were detected during aerobic and anaerobic growth, both with toluene as the sole carbon source [24]. These findings are in contrast to the regulatory pattern in Azoarcus sp. strain CIB and Magnetospirillum sp. strain TS-6, in which bss $A$ was not transcribed under oxic conditions in the presence of toluene [16,23]. To date, there is no sequence information available for regulator genes in strains DNT-1 and TS-6, which hampers the formulation of convincing mechanistic and eco-physiological explanations for these differences even among closely related strains. One hypothesis we would like to offer is that there are TdiS varieties which differ in their responses to toluene and benzylsuccinate: the "strain CIB type", which responds (predominantly) to benzylsuccinate [16], and the "strain 15-1 type" for which toluene is the principle effector. Still, this picture may not be complete since in strain CIB there was Tdi-independent activity of the bss promoter in the presence of toluene [16], and in strain 15-1 further components such as the XylR-like protein could play a role in bss expression, too.

Thirdly, and so-far unique to strain 15-1, the Tdi system encompasses the TdiC module. According to sequence analysis, this module may be involved in catabolite repression via sensing the cellular energy status. In strain CIB there is evidence that catabolite repression is co-regulating expression of the $b s s$ and $b b s$ genes, yet no regulatory element is known that could modulate activity of the Tdi two-component system in that strain [16]. Catabolite repression was also reported for various strains carrying out aerobic toluene degradation $[76,77]$. Such a regulatory feature would provide an obvious advantage for toluene-degrading microbes such as strain 15-1 that are catabolically versatile and thrive in habitats with comparable high fluxes of labile organic carbon.

Fourthly, there was no indication that nitrate needed to be present for transcribing the bss genes, which was suggested to be of importance for toluene-degrading denitrifiers [25]. In contrast, $b s s A$ transcription declined in cells grown anaerobically with toluene when the nitrate concentration was raised to $10 \mathrm{mM}$. It appears that this decline was specific since $b c r C$ transcription was not affected. We hypothesize that comparable high concentrations of denitrification intermediate(s) repress bss $A$ transcription. Nitric oxide (NO) has the highest chemical reactivity among the free intermediates and as a free radical NO has a strong propensity to interact with GREs. Although there is to our knowledge no biochemical data published on NO sensitivity of BSS, we assume that it is already inhibitory at $\mathrm{nM}$ concentrations. We further hypothesize that during denitrification the presence of high concentrations of nitrate resulted in a slightly increased steady-state level of NO, and that this increase, although minute, did have a measurable effect on bss expression. There was also a decrease in $b s s A$ expression in cells grown under oxic conditions after the addition of nitrate. In this study, we did not attempt to quantify denitrification rates under oxic conditions; however, this was 
described to occur in various other bacteria $[78,79]$, and denitrification did apparently take place in the oxic PFRs. The genome of strain 15-1 harbors eight members of the CRP/FNR superfamily with closest similarities to NO sensors/regulators, five of which were detected in cells grown under oxic and anoxic conditions (Figure S6). Such regulators control transcription of various genes including some involved in degradation of aromatic compounds [80], denitrification, oxidative stress response [60] and transcriptional regulation [81]. For instance, FnrL mediates transcriptional repression of members of the luxR family [81], to which tdiR belongs [19]. This type of repression could negatively affect BSS transcription in strain 15-1.

In conclusion, the regulatory scheme for BSS expression can be more complex than appreciated up to now. In Magnetospirillum sp. strain 15-1 thriving in the rhizosphere of a constructed wetland model, post-transcriptional control of BSS synthesis might endow the cells with an additional layer of regulation to cope better with their redox-dynamic environment. Furthermore, the metabolically versatile strain 15-1 appears to process various sensory inputs by other regulatory components in addition to the established TdiRS system to control the level of $b s s$ and $b b s$ transcription. Future information on regulation of BSS synthesis will allow for an improved assessment of anaerobic toluene degradation at contaminated sites.

Supplementary Materials: The following are available online at http://www.mdpi.com/2076-2607/8/5/681/s1, Figure S1: Growth of Magnetospirillum sp. 15-1 at different conditions, Figure S2: Pairwise alignment of TdiS and TdiR proteins among anaerobic toluene degraders, Figure S3: Transcriptional organization of $b s s, t d i$, and $b b s$ genes, Figure S4: Fold change averages of $b c r C$ expression in anaerobic and aerobic cultures of Magnetospirillum sp 15-1, Figure S5: Metabolic pathways detected in anaerobic and aerobic cultures of Magnetospirillum sp. 15-1, Figure S6: Phylogenetic tree of CRP/FNR regulators.Table S1: Identity (\%) of proteins involved in anaerobic toluene degradation among different degraders to Magnetospirillum sp. 15-1, Table S2: Detection of CRP/FNR superfamily members, Table S3: Culture pairs used to assess $b s s A$ and $b c r C$ expression from toluene-grown cells relative to $b s s A$ and $b c r C$ expression from benzoate-grown cells. Data set S1: qPCR raw data of $b s s A, b c r C$ and $16 \mathrm{~S}$ rRNA from AN and AB cultures, Data set S2: Copy numbers of $b s s A, b c r C$ and 16S rRNA from AN and AB cultures, Data set S3: Proteins identification and abundances from AN and AB cultures.

Author Contributions: I.M.-C., V.L. and J.A.M. conceived and designed the experiments; I.M.-C., S.G. performed the experiments; I.M.-C., S.-B.H., N.J. and J.A.M. analysed the data; N.J., M.v.B. and H.J.H. contributed reagents/ materials/analysis tools; I.M.-C., J.A.M. and H.J.H. wrote the paper. All authors have read and agreed to the published version of the manuscript.

Funding: This work was funded by CONICYT (grant $\mathrm{n}^{\circ}$ 72140034), Chile and by the Helmholtz Centre for Environmental Research-UFZ, Leipzig, Germany.

Acknowledgments: We thank the department of Isotope Biogeochemistry at UFZ for supplying necessary laboratory materials and equipment. We also want to thank to the Centre for Chemical Microscopy (ProVIS) at the UFZ for the preparation and visualization of Magnetospirillum sp. 15-1 samples. And we specially want to thank Ines Mäusezahl and Kerstin Ethner for their expert technical assistance and constant support.

Conflicts of Interest: The authors declare no conflict of interest. The founding sponsors had no role in the design of the study; in the collection, analyses, or interpretation of data; in the writing of the manuscript, and in the decision to publish the results.

\section{References}

1. Carmona, M.; Zamarro, M.T.; Blazquez, B.; Durante-Rodriguez, G.; Juarez, J.F.; Valderrama, J.A.; Barragan, M.J.; Garcia, J.L.; Diaz, E. Anaerobic catabolism of aromatic compounds: a genetic and genomic view. Microbiol. Mol. Biol. Rev. 2009, 73, 71-133. [CrossRef] [PubMed]

2. Fuchs, G. Anaerobic metabolism of aromatic compounds. Ann. N. Y. Acad. Sci. 2008, 1125, 82-99. [CrossRef] [PubMed]

3. Parales, R.E.; Parales, J.V.; Pelletier, D.A.; Ditty, J.L. Diversity of microbial toluene degradation pathways; Academic Press: Cambridge, MA, USA, 2008; volume 64, pp. 1-73.

4. Weelink, S.A.; van Eekert, M.H.A.; Stams, A.J.M. Degradation of BTEX by anaerobic bacteria: physiology and application. Rev. Environ. Sci. Biotechnol. 2010, 9, 359-385. [CrossRef]

5. Funk, M.A.; Judd, E.T.; Marsh, E.N.G.; Elliott, S.J.; Drennan, C.L. Structures of benzylsuccinate synthase elucidate roles of accessory subunits in glycyl radical enzyme activation and activity. Proc. Natl. Acad. Sci. USA 2014, 111, 10161-10166. [CrossRef] 
6. Funk, M.A.; Marsh, E.N.G.; Drennan, C.L. Substrate-bound structures of benzylsuccinate synthase reveal how toluene is activated in anaerobic hydrocarbon degradation. J. Biol. Chem. 2015, 290, 22398-22408. [CrossRef]

7. Leuthner, B.; Heider, J. Anaerobic toluene catabolism of Thauera aromatica: the bbs operon codes for enzymes of $\beta$ oxidation of the intermediate benzylsuccinate. J. Bacteriol. 2000, 182, 272-277. [CrossRef]

8. Fuchs, G.; Boll, M.; Heider, J. Microbial degradation of aromatic compounds - from one strategy to four. Nat. Rev. Microbiol. 2011, 9, 803-816. [CrossRef]

9. Kung, J.W.; Löffler, C.; Dörner, K.; Heintz, D.; Gallien, S.; Van Dorsselaer, A.; Friedrich, T.; Boll, M. Identification and characterization of the tungsten-containing class of benzoyl-coenzyme A reductases. Proc. Natl. Acad. Sci. USA 2009, 106, 17687-17692. [CrossRef]

10. Boll, M.; Fuchs, G.; Heider, J. Anaerobic oxidation of aromatic compounds and hydrocarbons. Curr. Opin. Chem. Biol. 2002, 6, 604-611. [CrossRef]

11. Widdel, F.; Rabus, R. Anaerobic biodegradation of saturated and aromatic hydrocarbons. Curr. Opin. Biotechnol. 2001, 12, 259-276. [CrossRef]

12. Sawers, G. Biochemistry, physiology and molecular biology of glycyl radical enzymes. FEMS Microbiol. Rev. 1998, 22, 543-551. [CrossRef]

13. Leuthner, B.; Leutwein, C.; Schulz, H.; Hörth, P.; Haehnel, W.; Schiltz, E.; Schägger, H.; Heider, J. Biochemical and genetic characterization of benzylsuccinate synthase from Thauera aromatica: a new glycyl radical enzyme catalyzing the first step in anaerobic toluene metabolism. Mol. Microbiol. 1998, 28, 615-628. [CrossRef] [PubMed]

14. Hilberg, M.; Pierik, A.J.; Bill, E.; Friedrich, T.; Lippert, M.; Heider, J. Identification of FeS clusters in the glycyl-radical enzyme benzylsuccinate synthase via EPR and Mössbauer spectroscopy. J. Biol. Inorg. Chem. 2012, 17, 49-56. [CrossRef] [PubMed]

15. Heider, J.; Szaleniec, M.; Martins, B.M.; Seyhan, D.; Buckel, W.; Golding, B.T. Structure and function of benzylsuccinate synthase and related fumarate-adding glycyl radical enzymes. J. Mol. Microbiol. Biotechnol. 2016, 26, 29-44. [CrossRef] [PubMed]

16. Blázquez, B.; Carmona, M.; Díaz, E. Transcriptional regulation of the peripheral pathway for the anaerobic catabolism of toluene and m-xylene in Azoarcus sp. CIB. Front. Microbiol. 2018, 9, 506. [CrossRef] [PubMed]

17. Achong, G.R.; Rodriguez, A.M.; Spormann, A.M. Benzylsuccinate synthase of Azoarcus sp. strain T: Cloning, sequencing, transcriptional organization and its role in anaerobic toluene and $m$-xylene mineralization. J. Bacteriol. 2001, 183, 6763-6770. [CrossRef]

18. Kube, M.; Heider, J.; Amann, J.; Hufnagel, P.; Kühner, S.; Beck, A.; Reinhardt, R.; Rabus, R. Genes involved in the anaerobic degradation of toluene in a denitrifying bacterium, strain EbN1. Arch. Microbiol. 2004, 181, 182-194. [CrossRef] [PubMed]

19. Leuthner, B.; Heider, J. A two-component system involved in regulation of anaerobic toluene metabolism in Thauera aromatica. FEMS Microbiol. Lett. 1998, 166, 35-41. [CrossRef]

20. Coschigano, P.W. Transcriptional analysis of the tutE tutFDGH gene cluster from Thauera aromatica strain T1. Appl. Environ. Microbiol. 2000, 66, 1147-1151. [CrossRef]

21. Coschigano, P.W.; Bishop, B.J. Role of benzylsuccinate in the induction of the tutE tutFDGH gene complex of T. aromatica strain T1. FEMS Microbiol. Lett. 2004, 231, 261-266. [CrossRef]

22. Kühner, S.; Wöhlbrand, L.; Fritz, I.; Wruck, W.; Hultschig, C.; Hufnagel, P.; Kube, M.; Reinhardt, R.; Rabus, R. Substrate-dependent regulation of anaerobic degradation pathways for toluene and ethylbenzene in a denitrifying bacterium, strain EbN1. J. Bacteriol. 2005, 187, 1493-1503. [CrossRef] [PubMed]

23. Shinoda, Y.; Akagi, J.; Uchihashi, Y.; Hiraishi, A.; Yukawa, H.; Yurimoto, H.; Sakai, Y.; Kato, N. Anaerobic degradation of aromatic compounds by Magnetospirillum strains isolation and degradation genes. Biosci. Biotech. Bioch. 2005, 69, 1483-1491. [CrossRef]

24. Shinoda, Y.; Sakai, Y.; Uenishi, H.; Uchihashi, Y.; Hiraishi, A.; Yukawa, H.; Yurimoto, H.; Kato, N. Aerobic and anaerobic toluene degradation by a newly isolated denitrifying bacterium, Thauera sp. strain DNT-1. Appl. Environ. Microbiol. 2004, 70, 1385-1392. [CrossRef] [PubMed]

25. Brow, C.N.; O’Brien Johnson, R.; Johnson, R.L.; Simon, H.M. Assessment of anaerobic toluene biodegradation activity by bssA transcript/gene ratios. Appl. Environ. Microbiol. 2013, 79, 5338-5344. [CrossRef]

26. Kappelmeyer, U.; Wiessner, A.; Kuschk, P.; Kästner, M. Operation of a universal test unit for planted soil filters- planted fixed bed reactor. Chem. Ing. Tech. 2002, 73, 1218. [CrossRef] 
27. Lünsmann, V.; Kappelmeyer, U.; Taubert, A.; Nijenhuis, I.; von Bergen, M.; Heipieper, H.J.; Müller, J.A.; Jehmlich, N. Aerobic toluene degraders in the rhizosphere of a constructed wetland model show diurnal polyhydroxyalkanoate metabolism. Appl. Environ. Microbiol. 2016, 8, 4126-4132. [CrossRef]

28. Meyer-Cifuentes, I.; Fiedler, S.; Müller, J.A.; Kappelmeyer, U.; Mäusezahl, I.; Heipieper, H.J. Draft genome sequence of Magnetospirillum sp. strain 15-1, a denitrifying toluene degrader isolated from a planted fixed-bed reactor. Genome Announc. 2017, 5, e00764-00717. [CrossRef]

29. Meyer-Cifuentes, I.; Martinez-Lavanchy, P.M.; Marin-Cevada, V.; Böhnke, S.; Harms, H.; Müller, J.A.; Heipieper, H.J. Isolation and characterization of Magnetospirillum sp. strain 15-1 as a representative anaerobic toluene-degrader from a constructed wetland model. PLoS ONE 2017, 12, e0174750. [CrossRef]

30. Tschech, A.; Fuchs, G. Anaerobic degradation of phenol by pure cultures of newly isolated denitrifying pseudomonads. Arch. Microbiol. 1987, 148, 213-217. [CrossRef]

31. Lane, D.J. 16S/23S rRNA sequencing; John Wiley and Sons, Ltd.: Chichester, UK, 1991; pp. 115-175.

32. Kuntze, K.; Vogt, C.; Richnow, H.H.; Boll, M. Combined application of PCR-based functional assays for the detection of aromatic-compound-degrading anaerobes. Appl. Environ. Microbiol. 2011, 77, 5056-5061. [CrossRef]

33. He, F. Bradford protein assay. Bio Protoc. 2011, 1, e45. [CrossRef]

34. Lünsmann, V.; Kappelmeyer, U.; Benndorf, R.; Martinez-Lavanchy, P.M.; Taubert, A.; Adrian, L.; Duarte, M.; Pieper, D.H.; von Bergen, M.; Müller, J.A.; et al. In situ protein-SIP highlights Burkholderiaceae as key players degrading toluene by para ring hydroxylation in a constructed wetland model. Environ. Microbiol. 2016, 18, 1176-1186. [CrossRef] [PubMed]

35. Brettin, T.; Davis, J.J.; Disz, T.; Edwards, R.A.; Gerdes, S.; Olsen, G.J.; Olson, R.; Overbeek, R.; Parrello, B.; Pusch, G.D.; et al. RASTtk: a modular and extensible implementation of the RAST algorithm for building custom annotation pipelines and annotating batches of genomes. Sci. Rep. 2015, 5, 8365. [CrossRef] [PubMed]

36. Overbeek, R.; Olson, R.; Pusch, G.D.; Olsen, G.J.; Davis, J.J.; Disz, T.; Edwards, R.A.; Gerdes, S.; Parrello, B.; Shukla, M.; et al. The SEED and the Rapid Annotation of microbial genomes using Subsystems Technology (RAST). Nucleic Acids Res. 2014, 42, D206-214. [CrossRef] [PubMed]

37. Aziz, R.K.; Bartels, D.; Best, A.A.; DeJongh, M.; Disz, T.; Edwards, R.A.; Formsma, K.; Gerdes, S.; Glass, E.M.; Kubal, M.; et al. The RAST Server: rapid annotations using subsystems technology. BMC Genom. 2008, 9, 75. [CrossRef]

38. Käll, L.; Canterbury, J.D.; Weston, J.; Noble, W.S.; MacCoss, M.J. Semi-supervised learning for peptide identification from shotgun proteomics datasets. Nat. Methods 2007, 4, 923. [CrossRef] [PubMed]

39. Chawade, A.; Alexandersson, E.; Levander, F. Normalyzer: a tool for rapid evaluation of normalization methods for omics data sets. J. Proteome Res. 2014, 13, 3114-3120. [CrossRef]

40. Välikangas, T.; Suomi, T.; Elo, L.L. A systematic evaluation of normalization methods in quantitative label-free proteomics. Brief Bioinform. 2018, 19, 1-11. [CrossRef] [PubMed]

41. Littlefield, K. Venn Diagram Plotter, 1.5.5228.29250; Batelle Memorial Institute, Department of Energy (PNNL): Richland, WA, USA, 2004.

42. Kanehisa, M.; Sato, Y.; Morishima, K. BlastKOALA and GhostKOALA: KEGG tools for functional characterization of genome and metagenome sequences. J. Mol. Biol. 2016, 428, 726-731. [CrossRef]

43. Letunic, I.; Yamada, T.; Kanehisa, M.; Bork, P. iPath: interactive exploration of biochemical pathways and networks. Trends Biochem. Sci. 2008, 33, 101-103. [CrossRef]

44. Yamada, T.; Letunic, I.; Okuda, S.; Kanehisa, M.; Bork, P. iPath2.0: interactive pathway explorer. Nucleic Acids Res. 2011, 39, W412-W415. [CrossRef] [PubMed]

45. Saeed, A.I.; Sharov, V.; White, J.; Li, J.; Liang, W.; Bhagabati, N.; Braisted, J.; Klapa, M.; Currier, T.; Thiagarajan, M.; et al. TM4: a free, open-source system for microarray data management and analysis. BioTechniques 2003, 34, 374-378. [CrossRef]

46. Singh, J. FigShare. J. Pharmacol. Pharmacother. 2011, 2, 138-139. [CrossRef]

47. Meyer-Cifuentes, I.; Gruhl, S.; Haange, S.B.; Lünsmann, V.; Jehmlich, N.; von Bergen, M.; Heipieper, H.J.; Müller, J. Data Set S1: qPCR raw data of bssA, bcrC and 16S rRNA from AN and AB cultures. Figshare 2020. [CrossRef] 
48. Meyer-Cifuentes, I.; Gruhl, S.; Haange, S.B.; Lünsmann, V.; Jehmlich, N.; von Bergen, M.; Heipieper, H.J.; Müller, J. Data Set S2: Copy numbers of bssA, bcrC and 16S rRNA from AN and AB cultures. Figshare 2020. [CrossRef]

49. Meyer-Cifuentes, I.; Gruhl, S.; Haange, S.B.; Lünsmann, V.; Jehmlich, N.; von Bergen, M.; Heipieper, H.J.; Müller, J. Data Set S3: Proteins identification and abundances from AN and AB cultures. Figshare 2020. [CrossRef]

50. Kim, S.J.; Park, S.J.; Jung, M.Y.; Kim, J.G.; Madsen, E.L.; Rhee, S.K. An uncultivated nitrate-reducing member of the genus Herminiimonas degrades toluene. Appl. Environ. Microbiol. 2014, 80, 3233-3243. [CrossRef]

51. Koh, S.; Hwang, J.; Guchhait, K.; Lee, E.G.; Kim, S.Y.; Kim, S.J.; Lee, S.; Chung, J.M.; Jung, H.S.; Lee, S.J.; et al. Molecular Insights into toluene sensing in the TodS/TodT signal transduction system. J. Biol. Chem. 2016, 291, 8575-8590. [CrossRef]

52. Ereño-Orbea, J.; Oyenarte, I.; Martinez-Cruz, L.A. CBS domains: Ligand binding sites and conformational variability. Arch. Biochem. Biophys. 2013, 540, 70-81. [CrossRef]

53. Kümmel, S.; Kuntze, K.; Vogt, C.; Boll, M.; Heider, J.; Richnow, H.H. Evidence for benzylsuccinate synthase subtypes obtained by using stable isotope tools. J. Bacteriol. 2013, 195, 4660-4667. [CrossRef]

54. Sawers, R.G.; Zenelein, E.; Böck, A. Two-dimensional gel electrophoretic analysis of Escherichia coli proteins: influence of various anaerobic growth conditions and the fnr gene product on cellular protein composition. Arch. Microbiol. 1988, 149, 240-244. [CrossRef] [PubMed]

55. Gunsalus, R.P.; Park, S.J. Aerobic-anaerobic gene regulation in Escherichia coli: control by the ArcAB and Fnr regulons. Res. Microbiol. 1994, 145, 437-450. [CrossRef]

56. Chiang, R.C.; Cavicchioli, R.; Gunsalus, R.P. Identification and characterization of narQ, a second nitrate sensor for nitrate-dependent gene regulation in Escherichia coli. Mol. Microbiol. 1992, 6, 1913-1923. [CrossRef] [PubMed]

57. Gunsalus, R.P.; Kalman, L.V.; Stewart, R.R. Nucleotide sequence of the narL gene that is involved in global regulation of nitrate controlled respiratory genes of Escherichia coli. Nucleic Acids Res. 1989, 17, 1965-1975. [CrossRef] [PubMed]

58. Li, J.; Kustu, S.; Stewart, V. In vitro Interaction of nitrate-responsive regulatory protein NarL with DNA target sequences in the $f d n G, n a r G$, narK and frdA operon control regions of Escherichia coli K-12. J. Mol. Biol. 1994, 241, 150-165. [CrossRef]

59. Rabin, R.S.; Stewart, V. Dual response regulators (NarL and NarP) interact with dual sensors (NarX and NarQ) to control nitrate- and nitrite-regulated gene expression in Escherichia coli K-12. J. Bacteriol. 1993, 175, 3259-3268. [CrossRef]

60. Körner, H.; Sofia, H.J.; Zumft, W.G. Phylogeny of the bacterial superfamily of Crp-Fnr transcription regulators: exploiting the metabolic spectrum by controlling alternative gene programs. FEMS Microbiol. Rev. 2003, 27, 559-592. [CrossRef]

61. Stewart, V. Nitrate regulation of anaerobic respiratory gene expression in Escherichia coli. Mol. Microbiol. 1993, 9, 425-434. [CrossRef]

62. Myers, K.S.; Yan, H.; Ong, I.M.; Chung, D.; Liang, K.; Tran, F.; Keleş, S.; Landick, R.; Kiley, P.J. Genome-scale analysis of Escherichia coli FNR reveals complex features of transcription factor binding. PLoS Genet. 2013, 9, e1003565. [CrossRef]

63. Schmidt, A.; Kochanowski, K.; Vedelaar, S.; Ahrne, E.; Volkmer, B.; Callipo, L.; Knoops, K.; Bauer, M.; Aebersold, R.; Heinemann, M. The quantitative and condition-dependent Escherichia coli proteome. Nat. Biotechnol. 2016, 34, 104-110. [CrossRef]

64. Hino, T.; Matsumoto, Y.; Nagano, S.; Sugimoto, H.; Fukumori, Y.; Murata, T.; Iwata, S.; Shiro, Y. Structural basis of biological $\mathrm{N}_{2} \mathrm{O}$ generation by bacterial nitric oxide reductase. Science 2010, 330, 1666-1670. [CrossRef] [PubMed]

65. Nnyepi, M.R.; Peng, Y.; Broderick, J.B. Inactivation of E. coli pyruvate formate-lyase: role of AdhE and small molecules. Arch. Biochem. Biophys. 2007, 459, 1913-1923. [CrossRef] [PubMed]

66. Shibata, N.; Toraya, T. Molecular architectures and functions of radical enzymes and their (re)activating proteins. J. Biochem. 2015, 158, 271-292. [CrossRef] [PubMed]

67. Hermuth, K.; Leuthner, B.; Heider, J. Operon structure and expression of the genes for benzylsuccinate synthase in Thauera aromatica strain K172. Arch. Microbiol. 2002, 177, 132-138. [CrossRef] 
68. Van Assche, E.; Van Puyvelde, S.; Vanderleyden, J.; Steenackers, H.P. RNA-binding proteins involved in post-transcriptional regulation in bacteria. Front. Microbiol. 2015, 6, 141. [CrossRef]

69. Picard, F.; Dressaire, C.; Girbal, L.; Cocaign-Bousquet, M. Examination of post-transcriptional regulations in prokaryotes by integrative biology. C. R. Biol. 2009, 332, 958-973. [CrossRef]

70. Potts, A.H.; Vakulskas, C.A.; Pannuri, A.; Yakhnin, H.; Babitzke, P.; Romeo, T. Global role of the bacterial post-transcriptional regulator CsrA revealed by integrated transcriptomics. Nat. Commun. 2017, 8, 1596. [CrossRef]

71. Holmqvist, E.; Wright, P.R.; Li, L.; Bischler, T.; Barquist, L.; Reinhardt, R.; Backofen, R.; Vogel, J. Global RNA recognition patterns of post-transcriptional regulators Hfq and CsrA revealed by UV crosslinking in vivo. EMBO J. 2016, 35, 991-1011. [CrossRef]

72. Kavanagh, K.L.; Jörnvall, H.; Persson, B.; Oppermann, U. Medium- and short-chain dehydrogenase/reductase gene and protein families: The SDR superfamily: functional and structural diversity within a family of metabolic and regulatory enzymes. Cell. Mol. Life Sci. 2008, 65, 3895-3906. [CrossRef]

73. Baker, M.E.; Grundy, W.N.; Elkan, C.P. Spinach CSP41, an mRNA-binding protein and ribonuclease, is homologous to nucleotide-sugar epimerases and hydroxysteroid dehydrogenases. Biochem. Biophys. Res. Commun. 1998, 248, 250-254. [CrossRef]

74. Stammers, D.K.; Ren, J.; Leslie, K.; Nichols, C.E.; Lamb, H.K.; Cocklin, S.; Dodds, A.; Hawkins, A.R. The structure of the negative transcriptional regulator NmrA reveals a structural superfamily which includes the short-chain dehydrogenase/reductases. EMBO J. 2001, 20, 6619-6626. [CrossRef] [PubMed]

75. LeGros, H.L.J.; Halim, A.B.; Geller, A.M.; Kotb, M. Cloning, expression, and functional characterization of the $\beta$ regulatory subunit of human methionine adenosyltransferase (MAT II). J. Biol. Chem. 2000, 254, 2359-2366. [CrossRef]

76. Duetz, W.A.; Marques, S.; Wind, B.; Ramos, J.L.; van Andel, J.G. Catabolite repression of the toluene degradation pathway in Pseudomonas putida harboring pWW0 under various conditions of nutrient limitation in chemostat culture. Appl. Environ. Microbiol. 1996, 62, 601-606. [CrossRef] [PubMed]

77. Busch, A.; Lacal, J.; Silva-Jimenez, H.; Krell, T.; Ramos, J.L. Catabolite repression of the TodS/TodT two-component system and effector-dependent transphosphorylation of TodT as the basis for toluene dioxygenase catabolic pathway control. J. Bacteriol. 2010, 192, 4246-4250. [CrossRef] [PubMed]

78. Robertson, L.A.; van Niel, E.W.; Torremans, R.A.; Kuenen, J.G. Simultaneous nitrification and denitrification in aerobic chemostat cultures of Thiosphaera pantotropha. Appl. Environ. Microbiol. 1988, 54, 2812-2818. [CrossRef]

79. Körner, H.; Zumft, W.G. Expression of denitrification enzymes in response to the dissolved oxygen level and respiratory substrate in continuous culture of Pseudomonas stutzeri. Appl. Environ. Microbiol. 1989, 55, 1670-1676. [CrossRef] [PubMed]

80. Durante-Rodríguez, G.; Gómez-Álvarez, H.; Nogales, J.; Carmona, M.; Díaz, E. One-component systems that regulate the expression of degradation pathways for aromatic compounds. In Cellular Ecophysiology of Microbe: Hydrocarbon and Lipid Interactions. Handbook of Hydrocarbon and Lipid Microbiology; Krell, T.E., Ed.; Springer International Publishing: Cham, Switzerland, 2018; pp. 137-175.

81. Ebert, M.; Laaß, S.; Thürmer, A.; Roselius, L.; Eckweiler, D.; Daniel, R.; Härtig, E.; Jahn, D. FnrL and three Dnr regulators are used for the metabolic adaptation to low oxygen tension in Dinoroseobacter shibae. Front. Microbiol. 2017, 8. [CrossRef] [PubMed]

(C) 2020 by the authors. Licensee MDPI, Basel, Switzerland. This article is an open access article distributed under the terms and conditions of the Creative Commons Attribution (CC BY) license (http://creativecommons.org/licenses/by/4.0/). 